\title{
Introduction: Repertoires of Representation
}

\author{
Harm Kaal and Daniëlle Slootjes
}

From classical societies to our modern age, ruling classes and their subjects have sought ways to communicate their rights and expectations to each other. Rulers have pursued avenues for legitimising and consolidating their position of power. Subjects in turn have looked for ways to express their loyalty or make known their discontent about their leaders. Over time and in different political systems, both leaders and those being led have developed and reshaped various modes of political communication to do so, be it oral, written, or material. ${ }^{1}$ This volume examines these various modes of political communication between rules and ruled from antiquity to the present day by the application of the concept of representation. This concept has proven its value in studies that explore the functioning of power relations. ${ }^{2}$

According to recent studies and public debate, political representation is in a state of crisis. The authority of the key institute of political representation parliament - and its members is subject to a fierce debate and the same goes for the status of political parties as the competent and trustworthy intermediaries between government and the people. ${ }^{3}$ Initiatives have been launched to develop alternative forms of political representation. ${ }^{4}$ Moreover, political scientists and philosophers have tried to come to terms with the recent historical trajectory of political representation. ${ }^{5}$ These studies have been added to an already vast body of scholarship on political representation that stretches out into the disciplines of political philosophy, political science, art history, cultural history and, of course, political history. Most of these studies are oriented towards the "formal" aspects of political representation, treating it as a status that results from particular political procedures and constitutional arrangements, and research is dedicated to an investigation of how representatives take up their role.

In a thought-provoking article on political representation, Michael Saward takes issue with such interpretations. Saward invites us to move away from a

1 Craig (1999) 119-161; Carey (2009).

2 Hall (1997); Pitkin (1967); Weber (2003).

3 Crouch (2004); Mair (2013).

4 Van Reybrouck (2013). Excerpts in English available via Van Reybrouck (2014).

5 Manin (1997); Rosanvallon (2008); Saward (2005). 
focus on "forms" of representation (such as trustees or delegates) and to ask ourselves the question, "what is going on in representation?" His answers revolve around the notion of claim making: what is going on in representation is that political actors are claiming to be representative. Rather than mirroring reality (mimesis), representation thus is constructed through the making of representative claims. He sees political representation as a "dynamic relationship" and stresses its "performative" and "aesthetic" aspects: "representing is performing $[\ldots]$ and the performance $[\ldots]$ adds up to a claim that someone is or can be 'representative."'6

Saward's main contribution to the historiography of modern political representation is that he offers a theoretical reflection that underpins recent deconstructions of political representation in the wake of the cultural and linguistic turn. For political historians, Saward's approach to political representation indeed sounds familiar. ${ }^{7}$ Since the 1980 s, a broad body of scholarship has emerged on the impact and meaning of the language and culture of politics in explaining the formation of political identities and constituencies, starting with Gareth Stedman Jones's work on the Chartist movement and Lynn Hunt's and Keith Michael Baker's studies on eighteenth century French political culture. ${ }^{8}$ Political constituencies, Jon Lawrence has argued, should not be treated as "pre-established social blocs awaiting representation," but seen as "painstakingly constructed [...] alliances." Political parties in turn were not the "passive beneficiaries of structural divisions within society," but "dynamic organizations actively involved in the definition of political interests and the construction of political alliances" through political discourse. ${ }^{9}$ The performative power of the language and culture of politics has also been taken up by German political historians such as Willibald Steinmetz and Thomas Mergel in explorations of both extremist and democratic politics. ${ }^{10}$

In this volume, building on Saward, we employ the concept of representation as an instrument that assists us in understanding the "dynamic relationship" between elites and the people which is shaped by the following two discursive practices. First of all, constructions of self-representation are being employed in the search for public display of one's power, be it of the individual ruler or of the collective of subjects. We define a variety of material and immaterial instruments that have been used to achieve and promote

\footnotetext{
$6 \quad$ Saward (2006) 302.

7 Saward does not seem to acknowledge this: he does not refer to any of the major historical studies on political representation mentioned in the notes below.

8 Stedman Jones (1983); Hunt (1984); Baker (1987); Baker (1990).

$9 \quad$ Lawrence (1993) 630-31.

$10 \quad$ Steinmetz (2011); Mergel (2010).
} 
self-representation, ranging from statues, coins, dress, manifestations to speeches, biographies, and interviews. Throughout the centuries these instruments have been at the heart of constructions of self-representation or Selbstdarstellung. ${ }^{11}$ Nevertheless, we also witness the emergence of new media or the abandonment of certain instruments that are no longer being regarded as effective (see for instance the chapters by Hekster, and Gijsenbergh and Leenders). In our effort to examine these constructions of self-representation and position them into a larger repertoire, it is important to consider their reception as well as contested or alternative constructions. Both rulers and subjects are agents and receptors within these constructions of self-representation. Furthermore, accessibility to rulers offers valuable insights into the representative relations between rulers and ruled. This requires us to take into account the various practices through which accessibility of rulers was shaped, expressed, and represented, which includes the visual and material culture that surrounded those in power (see the chapters by Van Berkel, Rietbergen, and Raeymaekers and Derks).

Second, representative claims are verbal acts through which political actors and institutions present themselves as representatives of others. Political actors such as politicians, leaders of social movements, or even "ordinary" citizens claim that they represent a particular group of people, that they speak on behalf of others (see the chapters by Van Meurs and Morozova, Kaal and Van der Griend). The same is applicable to institutions, ranging from parliament to less obvious institutions such as medieval religious orders (see the chapter by Roest) and present-day independent regulatory agencies (see the chapter by Van Veen). Deconstruction helps us to appreciate that through these claims people are in fact invited to understand themselves as a group that is being represented. This thus calls for an analysis of political communication, because here we find how a broad range of political actors define the nature and identity of those they claim to represent. ${ }^{12}$

Representative claims are "read back," that is, they are not merely imposed on a passive audience, but they are received and possibly also contested in various ways. We should therefore also explore political representation in interaction between the makers and recipients of representative claims (see the chapters by Van Meurs and Morozova, and Kaal and Van der Griend). Moreover, representative claims potentially have a "silencing effect": turning those who are claimed to be represented into a passive audience that is expected to put its trust into their representative. ${ }^{13}$

\footnotetext{
11 Weber (2003).

12 Saward (2006) 313-14. See for a more extensive account also Saward (2010).

13 Saward (2006) 303-04.
} 
Building on these two discursive practices, we aim to move away from normative and essentialist notions of political representation, as well as from limited, reductionist associations of political representation with the formal aspects of modern, democratic, electoral, and parliamentarian politics. In this volume, we bring together work on political representation conducted by scholars of Radboud University working on ancient, medieval, early modern, and modern political history. The research conducted by the political historians of the modern era on representative claim-making and self-representation acted as a starting point for a discussion with colleagues working on earlier eras. To what extent were the concepts that are at the heart of modern theories of political representation - such as representative claims and repertoires of representation - also applicable to earlier political systems and contexts? And to what extent are acts of (self-)representation built around similar practices and discourses throughout the ages? This set-up enabled us to integrate recent work by ancient, medieval, and early modern political historians, and the research conducted within the field of political science and communication, political philosophy, and modern political history. The latter includes innovative studies on deliberative democracy, on the interaction between formal and informal politics, and on practices of democracy, such as the recent work on petitioning by political scientist Dan Carpenter. ${ }^{14}$ The former have introduced new methods to explore the history of political representation from a constructivist, cultural perspective. This has, among others, resulted in new perspectives on the concept of political power through research on how Roman emperors, medieval kings, and the pope publicly represented themselves as a way of performing power. Such studies have drawn attention to the semiotics of representation in the form of symbols, rituals, festivities, dress, speech acts (and so forth). ${ }^{15}$ This invites us to also explore these elements of political representation for the modern era. But it also works the other way around: what has been argued for modern representative claims is also significant for scholars working on earlier eras. The public performance of power through a range of media like statues, parades, dress, coins, and architecture, for instance, also involved a negotiation of the reception of these representations of the political and again show that political representation is in essence a dynamic process.

Our volume does not offer a full-fledged diachronic overview, but we do aim to inspire scholars to delve deeper into the continuities (and breaks) at play in political representation. Chapters collected in this volume at least provide

\footnotetext{
14 Rollison (2010); Carpenter (in press); Kruke and Kufferath (2018); Landemore (2012); Fishkin (1995).

15 Braungart (2012).
} 
enough evidence to suggest that this is a path worth pursuing. Moreover, although the majority of the chapters focus on the European context, the chapter by medievalist Maaike van Berkel on the accessibility of Abbasid rulers at their courts shows striking similarities with Western repertoires of representation. She makes clear that it is also worthwhile for future researchers to widen their geographical scope and study political representation cross-culturally, exploring similarities and differences in practices and discourses of political representation not only across time, but also across space.

We contend that the construction of political representation involves a set of discourses, practices, and mechanisms that, although they have been applied and appropriated in various ways in a range of historical contexts, has stood the test of time. As a consequence, the contributions in our volume will demonstrate that, due to the continuity in certain customs and constructions of self-representation, the artificial boundaries between Antiquity, the Middle Ages or the Renaissance, and the modern era should be lifted. One can think, for instance, of the ceremonial surrounding the inauguration of Queen Elizabeth II of England in 1952 or that of King Willem Alexander of the Netherlands in 2013 to see the strong resemblance with the ceremonies of Roman or Karolingian emperors and kings. Modern kings and queens stand in a long tradition that we will fail to understand if we continue to apply artificial chronological boundaries. ${ }^{16}$ Moreover, our perspective allows us to connect the assemblies of the people and representative claims as they emerged in the early Roman Republic with those in the Middle Ages and later eras when parliaments arose. Indeed, the determination of the Roman tribune of the plebs Tiberius Gracchus to make the Roman people aware of their potential power shows similarities with later expressions throughout the states of Europe of popular leaders who offered to represent citizens within politics.

The contributions in this volume, which are presented in a chronological order, originate from a series of seminars in which the members of the Institute for Historical, Literary, and Cultural Studies at Radboud University reflected on the meaning of the concept of political representation in their field. In his chapter, Olivier Hekster shows that, in their representation of power, Roman emperors had to deal with institutionally and deeply entrenched senatorial elites. Hekster analyses imperial Roman representation in order to explore how the institutional basis of councillors surrounding a monarch influences and shapes competing representative claims of rulers and the circles revolving around them. Early emperors had to uphold the republican ideal that their extraordinary position was based on senatorial acclamation. Architecture, 
images, coins, and other visual sources are studied and show a mixed message of a superior senator annex monarch visible throughout Rome. The notion of Roman emperorship as tempered by senatorial advice remained strong, but the balance increasingly shifted towards councillors as supporting actors who belonged to the monarch. Although the distance between reality and representative claim had widened enormously over the centuries, the representative claim by senatorial councillors was maintained. Roman emperors continued to rule in a senatorial world, at least symbolically.

In her contribution, Maaike van Berkel focuses on the accessibility of rulers by analysing how access to the Abbasid Caliph was represented in (near)contemporary writings on the reign of Al-Muqtadir (r. 906-932). Van Berkel approaches access as a gradual and differentiated phenomenon shaped by cultural representations. Accessibility and simplicity were the ideal example of early Islam as epitomised by Mohammed himself, but were gradually replaced by the more hierarchical social models of the cultures the Muslims conquered. Although access to the Abbasid court became increasingly regulated, the seemingly contradictory discourses on the accessible yet distant ruler remained dominant. Al-Muqtadir's rule is an exception, as he is virtually solely represented as an inaccessible, distant Iranian ruler. In this case, representations of power closely resembled Al-Muqtadir who came to power at a young age and was dependent on his relatives and courtiers to rule. This perceived relationship of dependence resulted in ideals of accessible rulers being projected on the vizier, rather than his caliph.

The political nature of medieval religious orders is at the heart of Bert Roest's chapter. Roest argues that, in the historiography of medieval political thought and religious orders, the representative organisation in religious orders is often neglected. He demonstrates that religious orders were powerful, multinational organisations that played many roles within medieval society and influenced secular governance. Classical texts on political thought therefore need to be re-examined from this angle, as they were shaped by familiarity with religious modes of representation and delegation. Roest discusses Franciscan thought on and practices of representative government and urges historians to take it seriously. Franciscan ideals of evangelical equality gradually evolved in a balanced hierarchical administrative system. Later changes reinforced the executive power of provincial ministers and the minister general, but did not undermine the central tenets of the representative elements and priority attached to the legislative power of the general chapter. Franciscans played important roles in secular and ecclesiastical government, and their expertise, especially in technical matters, was drawn upon and applied in local representative government. 
In his contribution to this volume Peter Rietbergen analyses and compares the built environments of Rome and Versailles and their representations in print as rhetorical texts that proclaim a message of supreme power. Although Rome and Versailles are perceived as the prime embodiments of religious and secular monarchy, the distinctions were less clear-cut than often assumed. Both French and papal rulers' power representations were intimately shaped by conceptualisations of cosmic order and hierarchy legitimating their rule. Popes very much represented themselves with all the trappings of temporal monarchs, while the kings of France never ceased to present themselves in a religious, transcendental context as well. Both Rome and Versailles were constructed to face political challenges, respectively the Reformation and Humanism and power claims by urban elites and aristocrats. Both popes and kings exploited all aspects of visual propaganda, from religious iconology to print publications, thereby elevating the political rhetoric of capitals to a new height.

The issue of access is again taken up by Dries Raeymaekers and Sebastiaan Derks. Much like Van Berkel, they approach access primarily form a cultural perspective. Whereas previous historical research on the politics of access focused on physical access and its regulation to monarchs, their chapter widens the scope for future research by including the interconnected and complex practices in which the idea of access itself was shaped, expressed, and represented: the culture of access. Access was firstly a process of negotiation - a constant interplay of spaces, strategies, personalities, rituals, artefacts, and events - which was presented and visualised in varied ways and enacted through diverse repertoires of performances. By focusing on its representation, the manifold nature of arrangements characterising courtly life can be approached better in context, and its structures laid bare. Raeymaekers and Derks discuss four repertoires to study this: the articulation of space; the regulation of space; monopolising access; and visualising access, as in day-to-day practices, rituals, the visual and material culture of courts, architecture, and the politics of access are expressed.

Marij Leenders and Joris Gijsenbergh invite us to consider the modern era with their chapter on the ways in which the Dutch Prime Minister Hendrikus Colijn (1869-1944) has been depicted in photographs and cartoons. They show how the relationship between leaders and "the people" was a recurring theme in interwar debates on the system of political representation. Leenders and Gijsenbergh argue that visual sources offer insights into the ideals of political representation as they were presented to voters. Photographers, caricaturists, and (newspaper) editors influenced the reputation and representation of politics and attempted to legitimise and delegitimise certain types of leadership. Two repertoires of representing idealised leadership stand out: deliberative 
leadership, with leaders holding courteous, constructive discussions with MPs, and authoritative leadership or disciplined democracy, in which leaders largely ignored Parliament. The 1930s witnessed an important shift in representing representative politics: deliberative parliamentarianism did not disappear, but a strong leader now represented the nation, and photographs and caricatures delivered an important contribution to this image. Although some perceived this shift in the representation of political leadership as a threat to democracy, the vast majority, so Leenders and Gijsenbergh argue, welcomed it as an improvement of the system of parliamentary democracy.

Harm Kaal and Vincent van de Griend offer a critical examination of the current discourse of a crisis of political representation in both research and public debate. This discourse suffers from a lack of reflection on the multifaceted ways in which politicians and the people they represent interact. Historians, so they argue, must ask what went on in representation and explore the repertoires of communicative practices to study the interaction between the formal and informal worlds of politics. The authors identify four practices to explore popular perceptions of political representation and "the political": letters; television; opinion polls; and popular culture. They introduce a case study of letters written to the Dutch social-democratic party in the second half of the 1960s. These letters offer insight into how people experienced and responded to party developments, how they conceived themselves as political subjects, but also how the party itself responded to the "voice of the people." They claim that in order to incorporate the voice of the people in post-war political history, historians must study the communicative practices and media through which citizens have voiced their political opinions.

The chapter by Wim van Meurs and Olga Morozova concentrates on contemporary practices of representative claim-making in post-communist Ukraine. Van Meurs and Morozova compellingly show that representation in the sense of claiming to act on the behalf of others rests on legitimation. In 2014, opposition leader Julia Tymošenko, just released from prison, went to Majdan, Kyiv's main square in an attempt to turn herself into the leader of the popular revolt that had broken out. The crowd, however, failed to accept her claim that she would defend their interests. The protesters, as the authors argue, "refused to be 'led' or 'represented" and instead embraced the romantic ideal of popular sovereignty. Van Meurs and Morozova do not approach democratic representation or street politics through a normative lens, but instead explore explicit references and acknowledged role models by actors themselves in the dynamics of political contestation. The authors zoom in on Majdan square as a site of political contestation to study its layers of meanings and how actors diachronically link their repertoires of action and representative 
claims to the past. They argue that "Majdan" signifies a fundamental rejection of existing representative institutions and show how street politics acts as part of a repertoire with which "the people" contest politicians' representative claims.

In the final part of this volume Adriejan van Veen explores the representative claims of Independent Regulatory Authorities (IRA). Van Veen takes issues with the characterisation of IRAs as "unrepresentative" unelected bodies and goes on to show that they should be considered non-electoral representative claimants that wield considerable competences today. He offers an examination of four Dutch IRAs by applying Michael Saward's framework of representative claims. These IRAs have been instituted as independent bodies that are to represent economic and non-economic "public" interests in marketised and liberalised domains. Van Veen shows that the IRAs themselves increasingly claim to represent public and consumer activities in their public self-representation. Moreover, through their interaction with representatives of sectoral interests, IRAs are also confronted with a host of representative claims. Far from being unrepresentative, IRAs, thus, are representative claimants - and facilitators of representative claims. Independent market regulation involves the construction and reception of representative claims just as much as the traditional electoral sphere.

\section{Bibliography}

Baker, K.M., Inventing the French Revolution. Essays on French Political Culture in the Eighteenth Century (Cambridge, Eng., 1990).

Baker, K.M., (ed.), The French Revolution and the Creation of Modern Political Culture, vol. I, The Political Culture of the Old Regime (Oxford, 1987).

Braungart, W., Ästhetik der Politik, Ästhetik des Politischen: Ein Versuch in Thesen (Göttingen, 2012.

Carey, J.W., "A cultural approach to communication," in J.W. Carey (ed.), Communication as Culture: Essays on Media and Society (New York, 2009), 11-28.

Carpenter, D., Visions of the Republic: Petitions, Associations and Elections in Early America (in press).

Craig, R.T., "Communication Theory as a Field," in Communication Theory 9 (1999), 119-161.

Crouch, C., Post-Democracy (Cambridge, Eng., 2004).

Fishkin, J.S., The Voice of the People: Public Opinion and Democracy (New Haven and London, 1995).

Hall, S., (ed.), Cultural Representations and Signifying Practices (London, 1997). 
Hunt, L., Politics, Culture and Class in the French Revolution (Berkeley, 1984).

Kruke, A. and P. Kufferath, "Einleitung: Krisendiagnosen, Meistererzählungen und Alltagspraktiken. Aktuelle Forschungen und Narrationen zur Demokratiegeschichte in Westeuropa," in Archiv für Sozialgeschichte 58 (2018), 3-20.

Landemore, H., Democratic Reason. Politics, Collective Intelligence, and the Rule of the Many (Princeton and Oxford, 2012).

Mair, P., Ruling the Void. The Hollowing of Western Democracy (London, 2013).

Manin, B., The Principles of Representative Government (Cambridge, Eng., 1997).

Mergel, T., Propaganda nach Hitler: Eine Kulturgeschichte des Wahlkampfs in der Bundesrepublik 1949-199o (Göttingen, 2010).

Pitkin, H.F., The Concept of Representation (Berkely, 1967).

Reybrouck, D. van, "Against Elections," Policy Network, 23 October 2014, [accessed online 25.11.2018: <http://www.policy-network.net/pno_detail.aspx?ID=476o\&title= Against-elections $>$ ].

Reybrouck, D. van, Tegen verkiezingen (Amsterdam, 2013).

Rollison, D.A., Commonwealth of the People: Popular Politics and England's Long Social Revolution, 1066-1649 (Cambridge, Eng., 2010).

Rosanvallon, P., Counter-Democracy. Politics in an Age of Distrust (Cambridge, Eng., 2008).

Saward, M., The Representative Claim (Oxford, 2010).

Saward, M., "The Representative Claim," in Contemporary Political Theory 5 (2006), 297-318.

Saward, M., "Governance and the Transformation of Political Representation," in J. Newman (ed.), Remaking Governance: Peoples, Politics and the Public Sphere (Bristol, 2005), 179-196.

Stedman Jones, G., Languages of Class. Studies in English Working Class History (18321982 ) (Cambridge, Eng., 1983).

Steinmetz, W., (ed.), Political Languages in the Age of Extremes (Oxford, 2011).

Stollberg-Rillinger, B., Rituale (Frankfurt am Main/New York, 2013).

Weber, G. and M. Zimmermann (eds.), Propaganda-Selbstdarstellung-Repräsentation in römischen Kaiserreich des 1.Jhs. $n$. Chr. (Stuttgart, 2003). 